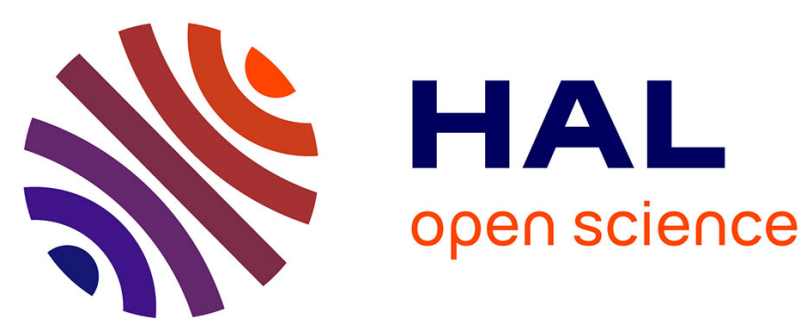

\title{
Organic carbon sources and transformations in mangrove sediments: A Rock-Eval pyrolysis approach
}

Cyril Marchand, Elisabeth Lallier-Vergès, Jean-Robert Disnar, Didier Kéravis

\section{To cite this version:}

Cyril Marchand, Elisabeth Lallier-Vergès, Jean-Robert Disnar, Didier Kéravis. Organic carbon sources and transformations in mangrove sediments: A Rock-Eval pyrolysis approach. Organic Geochemistry, 2008, 39 (4), pp.408-421. 10.1016/j.orggeochem.2008.01.018 . insu-00267322

HAL Id: insu-00267322

https://hal-insu.archives-ouvertes.fr/insu-00267322

Submitted on 27 Mar 2008

HAL is a multi-disciplinary open access archive for the deposit and dissemination of scientific research documents, whether they are published or not. The documents may come from teaching and research institutions in France or abroad, or from public or private research centers.
L'archive ouverte pluridisciplinaire HAL, est destinée au dépôt et à la diffusion de documents scientifiques de niveau recherche, publiés ou non, émanant des établissements d'enseignement et de recherche français ou étrangers, des laboratoires publics ou privés. 


\title{
Organic carbon sources and transformations in mangrove sediments: A Rock-Eval pyrolysis approach
}

\author{
C. Marchand ${ }^{\text {a, }}$ E. Lallier-Vergès ${ }^{a}$, J.-R. Disnar ${ }^{a}$ and D. Kéravis ${ }^{a}$ \\ ${ }^{a}$ Institut des Sciences de la Terre d'Orléans, CNRS/INSU, Université d'Orléans, 1A rue de la \\ Férollerie, 45071 Orléans, France
}

\begin{abstract}
A Rock-Eval pyrolysis study was carried out on sedimentary cores and leaf and woody tissue of vascular plant species from the mangroves of French Guiana. These forests develop on moving mudbanks and have a lifetime limited to few decades before being eroded. Our main purpose was to complete the understanding of carbon cycling in this specific environment using a method that allows monitoring the depth evolution of sources and transformation of organic matter (OM) within a tight depth span. Leaf and woody tissue showed clearly distinct Rock-Eval parameters. However, these parameters strongly varied with OM decomposition, rapidly limiting their efficiency as mangrove plant tracers. The decrease in values of TPS2 (pyrolysis temperature corresponding to the maximum release of hydrocarbons) with depth clearly showed a line between a pedogenetic layer enriched in autochthonous OM and marine sediments enriched in allochthonous OM. This allochthonous OM originated from the particulate discharge of the Amazon River, which is partly deflected northwestwards by the current of the Guianas. Within the soil layer, decay processes induced a strong dehydrogenation and slight oxidation of $\mathrm{OM}$, the two processes occurring simultaneously. The deeper layers were characterized by a very strong increase in $\mathrm{OICO}_{2}$ (quantity of pyrolysed $\mathrm{CO}_{2}$ relative to total organic carbon), beneath both the young and the senescent forests. This trend resulted rather from an increasing content of authigenic carbonate than from increasing concentration of oxidized allochthonous debris. Carbonate can form as a result of the more anoxic conditions prevailing in buried layers vs. the upper suboxic ones. Beneath the senescent mangrove, a greater increase in $\mathrm{OICO}_{2}$ probably reflected greater carbonate precipitation, resulting from the decomposition of higher amounts of OM.
\end{abstract}

\section{Introduction}

Mangrove forests are specific intertidal wetlands covering nearly $200,000 \mathrm{~km}^{2}$ along tropical and subtropical coastlines. They are among the most productive terrestrial ecosystems, with a total net primary production that can be estimated as up to $218 \pm 72 \mathrm{Tg} \mathrm{C}$ year $^{-1}$ (Bouillon et al., 2008). As a consequence, mangroves are considered to have a significant impact on global carbon cycling. Leaf litter and root systems provide the main organic input to the mangrove substrate. Nevertheless, there are a variety of other input sources, including algal production and allochthonous detritus that can be trapped (Kristensen et al., 2008). Due to the mixing of marine and fresh water and intense bioturbation, the organic matter (OM) in mangrove sediments is subject to intense decomposition under aerobic to sulfate reducing conditions ([Lallier-Vergès et al., 1998], [Alongi et al., 1999], [Alongi et al., 2000] and [Kristensen et al., 2000]). Nevertheless, part of this OM is preserved, and may help in palaeoenvironmental reconstruction (Versteegh et al., 2004).

In French Guiana, mangroves develop on homogeneous clayey sediments coming from the Amazon River. The Amazon discharge is partly deflected northwestwards by the current of the Guianas, and moves at $1.4 \mathrm{~km} /$ year toward the Orinoco River in the form of a series of 
mudbanks (Allison et al., 2000). One side of the mudbank is in accretion, while the other side undergoes erosion. As a consequence, mangrove deposits are stabilized only for 30-50 years until they are reset in suspension, when erosion reaches their settling place. In this specific context, Avicennia germinans is the dominant mangrove species, representing $>90 \%$ of mangrove trees (Fromard et al., 1998).

The Rock-Eval device is a temperature programmed pyrolyser, originally dedicated to petroleum exploration applications ([Espitalié et al., 1977], [Espitalié et al., 1985], [Dahl et al., 2004] and [Sachsenhofer et al., 2008]). Nevertheless, as a result of the simplicity and reliability of the method, it is also applied to trace OM sources and to follow OM transformation in soil and recent lake and marine sediments ([Ariztegui et al., 1996], [Patience et al., 1996], [Meyers and Lallier-Vergès, 1999], [Freudenthal et al., 2001], [Böttcher et al., 2003], [Disnard et al., 2003], [Jacob et al., 2004], [Sanei et al., 2005] and [Botz et al., 2007]). In previous studies ([Marchand et al., 2003] and [Marchand et al., 2005]), we used some Rock-Eval parameters, OM particle identification and counting under the microscope, stable isotopic data $\left(\delta^{13} \mathrm{C}\right.$ values) and molecular marker analysis (lignin and carbohydrates) to assess OM sources and diagenesis. These combined approaches revealed that the sedimentary OM was a blend of allochthonous refractory material deriving from Amazon River detritus and of autochthonous material inherited from algal mats and mangrove trees. In the present paper, our main objective was to complete our understanding of carbon cycling in these mangrove sediments using the whole Rock-Eval data set, including the following parameters: $\mathrm{OICO}, \mathrm{OICO}_{2}, \mathrm{TPS} 2$ and TPS3CO2. Accordingly, we aimed at assessing the potential of these Rock-Eval parameters as mangrove source tracers by comparing fresh mangrove tissue and sedimentary $\mathrm{OM}$ signatures. We also looked for parameters that might differentiate allochthonous OM from autochthonous OM. Then, we were interested in the relationships between the Rock-Eval parameters and diagenetic processes. Finally, we wanted to check a previous hypothesis on the origin of a strong OIRE6 increase with depth and the possible role of highly oxidized debris in this phenomenon (Marchand et al., 2003).

\section{Material and methods}

\subsection{Study site and sampling}

The mangroves are located on the right bank of the Sinnamary River, $50 \mathrm{~km}$ northwest of Kourou in French Guiana (Fig. 1). They develop on a huge mudbank, up to $30 \mathrm{~km}$ long and up to $5 \mathrm{~km}$ wide. The zonation of species commonly observed in many regions shows Rhizophora on the seaward fringe and Avicennia on a landward zone of higher elevation ([Hesse, 1961] and [McKee, 1995]), but does not occur in French Guiana. In contrast, the seaward zone exhibits nearly unispecific swamps (A. germinans) whose limit is parallel to the shoreline. Due to the dynamic feature of the coastline, a zonation can be made, differentiating the ages of A. germinans trees (Fig. 1). Scattered Laguncularia racemosa stands and Crenea maritima shrubs locally fringe the seaward side. Rhizophora mangle stands are present inside the estuaries or as patches in senescent Avicennia forests (Fromard et al., 1998). Samples were taken from 1 or $2 \mathrm{~m}$ long sedimentary cores. The cores were collected at low tide with an Eijkelkamp gouge auger in unvegetated sediments (C6-01), beneath a young mature mangrove stand (C1-01) and beneath a senescent mangrove stand (C12-01). Field observations reveal that the younger mangrove forests are reached by every flood tide. In contrast, the mature Avicennia zone is encountered on a higher topography that prevents all tides overflowing the soil and reaching the senescent mangroves, except spring tides. The 
study sites C1-01 and C12-01 are representative of this contrasting situation. Leaf and woody tissues were collected on several living trees surrounding the mud coring. Fieldwork was conducted in July 2001.

Along the coastline of French Guiana, 98\% of mangrove sediments originally come from the Amazon River and are mainly composed of clays (Allison et al., 1995). Thus, whatever the location of the sediment, the mineralogical composition remains essentially the same. Sandy layers, originating from local river input, are limited to a number of scattered cheniers, and were not sampled. As a consequence, the lithology of the cores was homogenous with depth or between mangrove stands. Optical observations and counts of organic constituents are presented by Marchand et al. (2003).

\subsection{Rock-Eval pyrolysis}

Analysis was carried out with $100 \mathrm{mg}$ of powdered sample using a "Turbo" Rock-Eval $6{ }^{\circledR}$ pyrolysis manufactured by Vinci ${ }^{\circledR}$ Technologies. The full description of the method and of the parameters obtained is given by (Espitalié et al., 1985) and (Lafargue et al., 1998). Briefly, samples are first pyrolysed under a inert $\mathrm{N}_{2}$ atmosphere and the residual carbon is subsequently burnt in an oxidation oven. The amount of hydrocarbons (HC) released during pyrolysis is detected with a flame ionisation detector (FID), while online infrared detectors measure continuously the released $\mathrm{CO}$ and $\mathrm{CO}_{2}$. The pyrolysis programme is: $200{ }^{\circ} \mathrm{C}(2 \mathrm{~min})$, then to $650{ }^{\circ} \mathrm{C}$ at $30^{\circ} \mathrm{C} \mathrm{min}^{-1}$ (hold $3 \mathrm{~min}$ ). The oxidation phase starts with an isothermal stage at $400{ }^{\circ} \mathrm{C}$, followed by an increase to $850{ }^{\circ} \mathrm{C}$ at $30{ }^{\circ} \mathrm{C} \mathrm{min}{ }^{-1}$ (hold $5 \mathrm{~min}$ ). Classical Rock-Eval parameters are calculated by integration of the amounts of $\mathrm{HC}, \mathrm{CO}$ and $\mathrm{CO}_{2}$ produced during thermal cracking of the OM, between well-defined temperature limits. Here, we focus mainly on the following parameters recorded during the pyrolysis phase:

- S2 (in $\mathrm{mg} \mathrm{HC} \mathrm{g}^{-1}$ sample); this corresponds to the amount of $\mathrm{HC}$ released.

- $\mathrm{S}_{3} \mathrm{CO}_{2}$ (mg $\mathrm{CO}_{2} \mathrm{~g}^{-1}$ sample), which corresponds to the amount of $\mathrm{CO}_{2}$ released before $400{ }^{\circ} \mathrm{C}$; this is to avoid interference from inorganic $\mathrm{CO}_{2}$ released at higher temperature.

- S3CO (mg CO g ${ }^{-1}$ sample), which corresponds to the amount of CO released; the upper boundary temperature corresponds to the temperature of lowest $\mathrm{CO}$ production between 450 and $600{ }^{\circ} \mathrm{C}$.

- TPS2, the temperature of the pyrolysis oven recorded at the top of the S2 peak, which thus corresponds to the optimum release of $\mathrm{HC}$.

- TPS3CO $\mathrm{CO}_{2}$, the temperature of the pyrolysis oven at the top of the $\mathrm{S}_{3} \mathrm{CO}_{2}$ peak, which thus corresponds to the maximum release of $\mathrm{CO}_{2}$ during pyrolysis. The maximum value is $400{ }^{\circ} \mathrm{C}$.

- Total organic carbon (TOC), the sum of all the carbon moieties ( $\mathrm{HC}, \mathrm{CO}$ and $\mathrm{CO}_{2}$ ) attributed to the decomposition of the $\mathrm{OM}$ and integrated during pyrolysis and the subsequent oxidation stage.

- HI, corresponding to the quantity of $\mathrm{HC}$ released relative to TOC, namely S2/TOC (in $\mathrm{mg}$ $\mathrm{HC} \mathrm{g}^{-1} \mathrm{TOC}$ ) and correlating with the $\mathrm{H} / \mathrm{C}$ ratio. 
- OICO, corresponding to the quantity of pyrolysed $\mathrm{CO}$ relative to $\mathrm{TOC}$, i.e. $\mathrm{S} 3 \mathrm{CO} / \mathrm{TOC}$ (in mg CO g ${ }^{-1}$ TOC).

$-\mathrm{OICO}_{2}$, corresponding to the quantity of pyrolysed $\mathrm{CO}_{2}$ relative to TOC, i.e. $\mathrm{S} 3 \mathrm{CO}_{2} / \mathrm{TOC}$ (in $\mathrm{mg} \mathrm{CO}_{2} \mathrm{~g}^{-1} \mathrm{TOC}$ ).

- OIRE6, corresponding to the quantity of oxygen released as $\mathrm{CO}$ and $\mathrm{CO}_{2}$ during pyrolysis, relative to TOC (in $\mathrm{mg} \mathrm{O}_{2} \mathrm{~g}^{-1}$ TOC and correlating with the $\mathrm{O} / \mathrm{C}$ ratio).

\section{Results and discussion}

\subsection{Rock-Eval parameters as source tracers}

\subsubsection{Fresh mangrove tissue signature}

Results of Rock-Eval pyrolysis of leaf and woody tissues of the four mangrove species developing in Sinnamary's mangrove (A. germinans, $R$. mangle, L. racemosa and $C$. maritima) are presented in Table 1 and Fig. 2. At least three parameters were clearly different between wood and leaves. HI values were relatively high and, except for Rhizophora, were slightly higher for the leaves than for the wood, i.e. from 420 to $556 \mathrm{mg} \mathrm{HC} \mathrm{g}^{-1}$ TOC vs. 323 to $480 \mathrm{mg} \mathrm{HC} \mathrm{g}^{-1}$ TOC (Table 1). These high values highlighted a high degree of $\mathrm{OM}$ hydrogenation. Higher plant debris is poor in hydrocarbon-like compounds but rich in cellulose and lignin, which may have induced low HI values. However, it is now known that the epicuticular wax of terrestrial plants, which comprises hydrogen-rich compounds, can produce high HI values, similar to those of algae and microbial biomass ([Meyers, 1997], [DiGiovanni et al., 1998] and [Lüniger and Schwark, 2002]). The fact that Rhizophora leaves were characterized by relatively low values may be related to specific wax content. Few studies have been interested in analysing fresh tissue; however, our results are consistent with those obtained with leaf litter of holly and oak which displayed rather high HI values ([DiGiovanni et al., 1998] and [Disnard et al., 2003]). The fact that mangrove wood was characterized by slightly lower HI values than leaves may be linked to a higher, or even nearly exclusive, ligno-cellulose content (Marchand et al., 2005). FID pyrograms (Fig. 2), from which HI values are derived, do not display a simple Gaussian-like distribution like ancient sediments, but rather a sum of several peaks ([Disnard et al., 2003], [Hetényi et al., 2005] and [Sebag et al., 2006]). These studies support and confirm previous work (e.g. Disnar and Trichet, 1984) demonstrating that all peaks correspond to the cracking of organic compounds of different thermal stability. Concerning mangrove wood samples, values of TPS2, the temperature of maximum HC release, were $350^{\circ} \mathrm{C}$ whatever the species. This temperature is characteristic of ligno-cellulose compounds (Disnard et al., 2003), highlighting the dominance of these constituents in mangrove tree wood. In pyrograms of mangrove leaves, the peak maximizing at $350{ }^{\circ} \mathrm{C}$ was less intense than for the corresponding wood and was accompanied by more shoulders, thereby reflecting a more diverse composition. As a result, TPS2 varied between 341 and $387^{\circ} \mathrm{C}$. Two other Rock-Eval parameters were clearly different between the leaves and the wood. TPS $3 \mathrm{CO}_{2}$, which corresponds to the temperature of maximum $\mathrm{CO}_{2}$ release during pyrolysis, was $60{ }^{\circ} \mathrm{C}$ higher for the wood than for the leaves. Finally, the OICO values ranged between 44 and $50 \mathrm{mg} \mathrm{CO} \mathrm{g}^{-1} \mathrm{TOC}$, and between 58 and $83 \mathrm{mg} \mathrm{CO} \mathrm{g}^{-1}$ TOC, for the leaves and the wood, respectively (Table 1). Both these parameters thus reflected a greater proportion of rather labile oxygenated functional groups in leaves than in wood (e.g. carboxyl vs. ether). 


\subsubsection{Autochthonous origin of sedimentary $O M$}

The above parameters help in distinguishing OM inheritance in mangrove sediments. In the unvegetated core, HI values were close to $140 \mathrm{mg} \mathrm{HC} \mathrm{g}^{-1} \mathrm{TOC}$ (Table 2). In contrast, they were close to $190 \mathrm{mg} \mathrm{HC} \mathrm{g}^{-1} \mathrm{TOC}$ in the upper $10 \mathrm{~cm}$ of the young mangrove (Table 3), and up to $400 \mathrm{mg} \mathrm{HC} \mathrm{g}^{-1} \mathrm{TOC}$ in the sediment beneath the senescent forest (Table 4). These results highlight an increasing contribution of fresh higher plant detritus to the sedimentary OM with increasing development of the forest. As a matter of fact, they are in agreement with independent optical observations showing an increased proportion of well-preserved lignocellulose debris, and a decrease in algal-derived greyish amorphous OM with forest age (Marchand et al., 2003). Beneath the senescent mangrove, the highest HI value, i.e. $456 \mathrm{mg}$ $\mathrm{HC} \mathrm{g}^{-1} \mathrm{TOC}$, was measured for the upper $2 \mathrm{~cm}$. The fact that this sample was characterized by the lowest OICO (48 mg CO g ${ }^{-1}$ TOC) and lowest $\mathrm{TPS}_{3} \mathrm{CO}_{2}$ values, indicated a strong contribution of mangrove leaves to the sedimentary OM, which did not appear beneath the young mangrove because of tidal export (Marchand et al., 2003). This result is consistent with the high hemicellulose content, characteristic of leaves, found in the same sample (Marchand et al., 2005). Nevertheless, the evolution of these parameters with diagenesis (see below) limits their application as mangrove source tracers to the really early stages of decomposition. In a general way, in all the mangrove swamps studied, the highest HI values were measured for the upper layers, which were also characterized by higher $\mathrm{C} / \mathrm{N}$ values, higher carbohydrate and phenol contents, and lower $\delta^{13} \mathrm{C}$ values (Marchand et al., 2005), thus confirming the importance of the contribution of higher plant material to the sedimentary OM.

\subsubsection{Evidence for allochthonous inputs}

Beneath the senescent forest, two groups of samples can be differentiated (Fig. 3A). On one hand, samples from the upper $35 \mathrm{~cm}$ of the core were all characterized by a TPS2 of $450{ }^{\circ} \mathrm{C}$ (Fig. 3B; Table 4). On the other hand, samples belonging to the bottom of the core were surprisingly characterized by a low TPS2 value of $340^{\circ} \mathrm{C}$ (Fig. 3C; Table 4). These low TPS2 values were close to those of fresh tissue and typical of cellulose-rich OM. However, and as confirmed by the low TOC and HI values, the deep sediment layers were not subject to the introduction of fresh higher plant-derived OM. In contrast, these deep sediments were characterized by the presence of highly oxidized organic debris derived from higher plants, evidenced as abundant opaque lignocellulose particles under the microscope, and lower $\delta^{13} \mathrm{C}$ values ([Marchand et al., 2003] and [Marchand et al., 2005]). Since these minute debris particles were also dominant in the unvegetated sediment, we suggested that this OM was allochthonous, arising from the Amazonian detritus and transported with the mudbank. TPS2 values close to $350{ }^{\circ} \mathrm{C}$ found in deep layers and in unvegetated sediments are typical for labile organic constituents. This finding is consistent with previous results which showed that these sediments were surprisingly rich in carbohydrate and more specifically in deoxy sugars, rhamnose and fucose (Marchand et al., 2005). High deoxy sugar content, corresponding to increased microbial degradation, was a characteristic of the fine particulate organic material from the Amazon River, confirming our hypothesis on its origin ([Hedges et al., 1986] and [Hedges et al., 1994]). These carbohydrates may have been subjected to selective preservation by adsorption on to clay minerals. Consequently, the low TPS2 values found in these deep sediments consolidated our hypothesis of an allochthonous origin of OM at depth. We suggest that TPS2 can thus be considered as a good indicator of the limit between a pedogenetic layer primarily enriched in autochthonous OM (TPS2 $450^{\circ} \mathrm{C}$ ) and a sedimentary layer enriched in allochthonous OM (TPS2 $340^{\circ} \mathrm{C}$ ). The limit delineated by TPS2 values was at $15 \mathrm{~cm}$ beneath 
the young mature forest (Table 3) and at $35 \mathrm{~cm}$ beneath the senescent one (Table 4), thus highlighting the development of a soil on marine sediments as result of forest development.

\subsection{Rock-Eval parameters and diagenetic processes}

The HI-OIRE6 depth evolution within the two sample sets was also strictly different (Fig. 3A). The first group was delineated by a strong $\mathrm{HI}$ decrease from 456 to $89 \mathrm{mg} \mathrm{HC} \mathrm{g}^{-1}$ TOC, and the second group by a strong increase in OIRE6 values, from 170 to $722 \mathrm{mg} \mathrm{O}_{2} \mathrm{~g}^{-1} \mathrm{TOC}$.

\subsubsection{Autochthonous OM diagenesis}

For the upper layer, TPS2 values at $450{ }^{\circ} \mathrm{C}$ were consistent with those obtained for uppermost horizons of forest soils (most $\mathrm{OH}$ and all A and B horizons; Disnard et al., 2003). The shift from $350{ }^{\circ} \mathrm{C}$ in mangrove plant to $450{ }^{\circ} \mathrm{C}$ in the soil layer, reflects the rapid loss of some labile compounds in the early stages of diagenesis, either by simple leaching and/or through microbial processes affecting the litter. The $450{ }^{\circ} \mathrm{C}$ value is much higher than the TPS 2 value (temperature at the maximum in the pyrolysis peak) of fresh tissue. This probably means that the compounds responsible for the peak were not biological components but more probably humic ones, as suggested by Disnard et al. (2003) for temperatures $>400{ }^{\circ} \mathrm{C}$ for the top of the peak that were recorded for organo-mineral soil horizons. In a previous study (Marchand et al., 2005), we showed that carbohydrates were rapidly degraded at the sediment water interface in the young mangroves, or in the litter in the older ones. Effectively, carbohydrates, which are the most abundant plant components, represented between $15 \%$ and $35 \%$ of the TOC in mangrove tissue but less than $9 \%$ in mangrove sediments. Conversely, lignin-derived phenols represented less than 5\% of TOC in mangrove plants but usually more in the sediments (namely 2-17\%) as a consequence of their rather refractory character. Consequently, we propose that the TPS2 increase between mangrove plants and sediments mostly reflects the loss of carbohydrate during the early stages of diagenesis.

In this upper layer, HI values strongly decreased, being 5 times lower at 35 than at $5 \mathrm{~cm}$ depth (Table 4). This lowering indicated efficient dehydrogenation of higher plant-derived OM, which occurred even in waterlogged marine sediments. In the meantime, OIRE6 values slightly increased, from 110 to $170 \mathrm{mg} \mathrm{O}_{2} \mathrm{~g}^{-1}$ TOC (Table 4), showing that OM oxidation occurred in the same time as dehydrogenation. OM decomposition also induced a slight increase in $\mathrm{TPS}_{3} \mathrm{CO}_{2}$, from 350 to $390{ }^{\circ} \mathrm{C}$ (Fig. 4C and E), highlighting a more refractory character for the "diagenetised" OM.

\subsubsection{Signal perturbation by inorganic carbon}

The deeper layers, both beneath the young and the senescent forests, were characterized by a strong OIRE6 increase. Because of the dominance of allochthonous higher plant-derived OM in the deep sediment layers -highlighted by optical observations, $\delta^{13} \mathrm{C}$ values, and molecular composition ([Marchand et al., 2003] and [Marchand et al., 2005]) - we hypothesized that the OIRE6 increase with depth was correlated with increasing amounts of the highly oxidized debris, rather than by the progressive oxidation of autochthonous material (Marchand et al., 2003). Our new analyses showed that the increase in OIRE6 values, between 35 and $70 \mathrm{~cm}$ depth, mainly originated from an increase of $\mathrm{OICO}_{2}$, which effectively rose from 177 to $908 \mathrm{mg} \mathrm{CO} \mathrm{g}^{-1}$ TOC, whereas OICO only slightly increased from 72 to $108 \mathrm{mg} \mathrm{CO} \mathrm{g}^{-1}$ TOC. Additionally, samples that were characterized by the highest $\mathrm{OICO}_{2}$ values were also characterized by the highest $\mathrm{TPS}_{3} \mathrm{CO}_{2}$ value, $400{ }^{\circ} \mathrm{C}$ (i.e. the maximum temperature of 
recording of this parameter; see Section 2). $\mathrm{CO}_{2}$ pyrograms also changed significantly between the upper and the deep sediment layers (Fig. 4E and F). In the upper core, the $\mathrm{CO}_{2}$ release intensity decreased with depth, while the temperature of maximum release $\left(\mathrm{TPS} 3 \mathrm{CO}_{2}\right)$ increased slightly, highlighting the preferential decomposition of the more labile oxygenated groups with OM diagenesis. In contrast, at depth in the young as well as in the senescent mangroves, TPS $3 \mathrm{CO}_{2}$ remained identical for all samples and slightly higher than $400{ }^{\circ} \mathrm{C}$ (Fig. $4 \mathrm{D}$ and F). In Rock-Eval pyrolysis, $\mathrm{CO}_{2}$ release at a temperature higher than $400{ }^{\circ} \mathrm{C}$ is supposed to be due to mineral products ([Lafargue et al., 1998] and [Tamburini et al., 2002]). In French Guiana, 98\% of mangrove sediments originally come from the Amazon River and are composed of clays, namely illite, chlorite, kaolinite and smectite (Parra and Pujos, 1998). The nearly or even total absence of carbonate was also proven by Rock-Eval TOC values that were very close to total carbon (TC) values determined from combustion with a LECO analyser (Fig. 5). However, Zhu et al. (2002) described mixed $\mathrm{Ca}, \mathrm{Mg}, \mathrm{Fe}, \mathrm{Mn}$ authigenic carbonates upstream of the mobile mud of the coast of the Guianas. In addition, subtidal deposits of the Sinnamary mudbank are often supersaturated with respect to $\mathrm{MnCO}_{3}$ a few centimetres below the oxidized layer (Aller et al., 2004). Consequently, in order to check for the possible presence of a few carbonates and their part in the observed $\mathrm{CO}_{2}$ release, some samples from the upper and bottom layers of the various cores were subjected to $\mathrm{HCl}$ treatment. This did not give any significant result for the upper sediment. The treated samples were characterized by higher TPS2, and slightly lower TOC and HI values, revealing that in addition to its ability to remove carbonate, $\mathrm{HCl}$ also removed some labile organic compounds. However, it induced a strong decrease in $\mathrm{OICO}_{2}$ for the deeper layer samples (Table 5). Additionally, $\mathrm{CO}_{2}$ pyrograms were strictly different before and after $\mathrm{HCl}$ treatment, confirming the mineral origin of the $\mathrm{CO}_{2}$ evolved from the untreated samples (Fig. 6). To try to confirm the possible presence of such minerals in our samples, we then performed RockEval pyrolysis (Fig. 7) on well-crystallized siderite $\left(\mathrm{FeCO}_{3}\right)$ and rhodochrosite $\left(\mathrm{MnCO}_{3}\right)$. Both these minerals released high quantities of $\mathrm{CO}_{2}$ during pyrolysis. However, in contrast to $\mathrm{FeCO}_{3}, \mathrm{MnCO}_{3}$ did not release a lot of $\mathrm{CO}$. Consequently, this suggests that the observed IORE6 rise may be caused by an increase in $\mathrm{CO}_{2}$ release due to higher $\mathrm{MnCO}_{3}$ amounts in deeper samples. Consistently, in all the mangrove swamps studied, total Mn concentration increased with depth, reaching up to $0.2 \%$ (Marchand et al., 2006a). In fact, depth profiles of $\mathrm{OICO}_{2}$ and $\mathrm{Mn}$ content were very similar (Fig. 4A and B). Consequently, we suggest that, in mangrove sediments, some neosynthesis of authigenic carbonates happened, and that specific $\mathrm{OICO}_{2}$ depth profiles mainly result from the dissolution/precipitation of these carbonates. The difference between the soil and the sediment layers can be explained by the redox trend with depth. In the young mangrove swamps, suboxic to oxic processes develop to a depth of $30 \mathrm{~cm}$ whatever the season (Marchand et al., 2004). These conditions result from the ability of $A$. germinans trees to aerate the sediment at the root level, provided that the sedimentary organic content is low (Scholander et al., 1955). Below $30 \mathrm{~cm}$, sediments were always anoxic. In the older mangroves, characterized by a higher organic content and exempt from daily tidal inundation, the depth evolution of redox potential is clearly different than in the younger stages and changes seasonally (Marchand et al., 2004). During the rainy season, the water table is high and the whole depth profile is anoxic. Conversely during the dry season, the desiccation of the upper sediment adds its oxidation effect to that of root activity. As a result, oxic to suboxic conditions dominate in the upper $20 \mathrm{~cm}$ and a zone of sulfate reduction underlies a zone of sulfide oxidation (Marchand et al., 2004). To summarize, for at least part of the year, the pedogenetic layer is characterized by suboxic to oxic conditions, which prevent carbonate precipitation. However, in deeper sediments carbonate precipitation is favoured by permanent anoxia. 
Differences in $\mathrm{OICO}_{2}$ values and the shape of $\mathrm{CO}_{2}$ pyrograms for deep sediment layers, beneath the young and the senescent mangroves, may highlight differences in the neosynthesis of carbonate. During the pyrolysis of samples collected at depth beneath the older swamp, there was a more intense release of $\mathrm{CO}_{2}$. This result can reflect a higher content of authigenic carbonate beneath the senescent forest than in the young forest. Actually, the old swamp was characterized by a higher organic content, probably leading to a higher production of dissolved inorganic carbon (DIC) during OM decomposition. In a previous study (Marchand et al., 2006b), in order to explain high dissolved organic carbon (DOC) concentrations and high salinity values in the deeper sediment, we suggested that the percolation of gravitational water may induce a transport of salt and DOC to greater depths, where they can accumulate. Accordingly, we suggest here that DIC produced by OM decomposition in the pedogenetic layer, may migrate with percolating water to anoxic deeper layers where carbonates can precipitate. This process may explain higher authigenic carbonate formation beneath the senescent forest and thus a higher $\mathrm{CO}_{2}$ production during pyrolysis.

\section{Conclusions}

Although this study illustrates that Rock-Eval pyrolysis application requires a good knowledge of the depositional environment, the method turned out to be a powerful tool for following qualitatively and quantitatively the diagenetic transformation of higher plantderived OM within coastal marine sediments. Unfortunately, the evolution of most Rock-Eval parameters with diagenesis limits their application in tracing plant sources. The main other conclusions of the study can be summarized as follows:

1. Rock-Eval pyrolysis of fresh mangrove plant tissues reflected their compositional differences. Mangrove leaf and woody tissues were both characterized by relatively high HI values, but slightly lower values for mangrove wood reflected the higher content in lignocellulose compounds. Most mangrove plant tissue had a temperature of maximum HC release (TPS2) close to the temperature of cellulose thermal cracking, consistent with the natural abundance of this component. Finally, $\mathrm{CO}$ and $\mathrm{CO}_{2}$ release during pyrolysis also differed slightly between wood and leaves, the latter being characterized by lower $\mathrm{TPS} \mathrm{CO}_{2}$ and OICO values indicative of an overall more labile character.

2. The depth evolution of Rock-Eval parameters within the sediment highlighted changes in $\mathrm{OM}$ quality as a combined result of sources variation and diagenetic processes. TPS2 values distinguished two different layers, thus confirming that $\mathrm{OM}$ was a blend between an autochthonous OM component derived from mangrove trees and an allochthonous OM component from the Amazonian detritism. The upper sediment displayed TPS2 values typical of humic substances derived from autochthonous mangrove plants, whereas at depth TPS2 reflected the richness in carbohydrate from OM that was confirmed to be allochthonous. Except for the upper sediment of the senescent mangrove that was clearly rich in OM derived from leaf litter, it was not possible to distinguish OM derived from leaves or from wood. The depth trend in Rock-Eval parameters also reflected OM transformation. The upper layers were characterized by a strong HI decrease and a slight OIRE6 increase, highlighting the fact that dehydrogenation and oxidation occur at the same time during OM decomposition. Additionally, the temperature of maximum $\mathrm{CO}_{2}$ release increased with $\mathrm{OM}$ diagenesis, evidencing increasing stability of the newly formed humic substances.

3. A previous hypothesis relating the strong OIRE6 increase in the deep layer to the accumulation of highly oxidized allochthonous debris (Marchand et al., 2003) was 
invalidated. In fact, this Rock-Eval signal anomaly resulted from the release of $\mathrm{CO}_{2}$ at relatively low pyrolysis temperature from probably poorly crystallized, and thus low stability, mineral phases. We suggest that the decomposition of autochthonous $\mathrm{OM}$ in the pedogenetic layer leads to the production of DIC that can migrate to deeper marine sediments, where carbonates can precipitate because of the marked anoxic conditions that prevail there compared to the upper suboxic layers. The higher the organic content of the soil layer, the higher the OIRE6 values of the sediment layer, probably reflecting the greater carbonate precipitation. Finally, we suggest that carbonate neo-synthesis may be a significant sink for carbon in mangrove sediments.

\section{Acknowledgements}

The research was supported by INSU and the PNEC Guyane. We would like to thank F. Baltzer (Université Paris XI, France) for valuable assistance in the field and for fruitful discussions, M. Hatton (ISTO, Orléans, France) for technical assistance and two anonymous reviewers for constructive comments.

\section{References}

Aller et al., 2004 R.C. Aller, C. Heilbrun, C. Panzeca, Z. Zhu and F. Baltzer, Coupling between sedimentary dynamics, early diagenetic processes, and biogeochemical cycling in the Amazon-Guianas mobile mud belt: coastal French Guiana, Marine Geology 208 (2004), pp. $331-360$.

Allison et al., 1995 M.A. Allison, C.A. Nittrouer and L.E.C. Faria Jr., Rates and mechanisms of shoreface progradation and retreat downdrift of the Amazon River mouth, Marine Geology 125 (1995), pp. 373-392

Allison et al., 2000 M.A. Allison, M.T. Lee, A.S. Ogston and R.C. Aller, Origin of Amazon mudbanks along the northeastern coast of South America, Marine Geology 163 (2000), pp. 241-256.

Alongi et al., 1999 D.M. Alongi, F. Tirendi, L.A. Trott and G.J. Brunskill, Mineralization of organic matter in intertidal sediments of a tropical semi-enclosed delta, Estuarine Coastal and Shelf Sciences 48 (1999), pp. 451-467.

Alongi et al., 2000 D.M. Alongi, F. Tirendi and B.F. Clough, Belowground decomposition of organic matter in forests of the mangrove Rhizophora stylosa and Avicennia marina along the arid coast of Western Australia, Aquatic Botany 68 (2000), pp. 97-122.

Ariztegui et al., 1996 D. Ariztegui, P. Farrimond and J.A. McKenzie, Compositional variations in sedimentary lacustrine organic matter and their implications for high Alpine Holocene environmental changes/lake St Moritz, Organic Geochemistry 24 (1996), pp. 453461.

Böttcher et al., 2003 M.E. Böttcher, J. Rinna, B. Warning, R. Wehausen, M.W. Howell, B. Schnetger, R. Stein, H.-J. Brumsack and J. Rullkötter, Geochemistry of sediments from the 
connection between the western and the eastern Mediterranean Sea (Strait of Sicily, ODP Site 963), Palaeogeography, Palaeoclimatology, Palaeoecology 190 (2003), pp. 165-194.

Botz et al., 2007 R. Botz, M. Schmidt, H. Wehner, H. Hufnagel and P. Stoffers, Organic-rich sediments in brine-filled Shaban and Kebrit deeps, northern Red Sea, Chemical Geology 244 (2007), pp. 520-553.

Bouillon et al., 2008 Bouillon, S., Borges, A.V., Castañeda-Moya, E., Diele, K., Dittmar, T., Duke, N.C., Kristensen, E., Lee, S.Y., Marchand, C., Middelburg, J.J., Rivera-Monroy, V.H., Smith III, T.J., Twilley, R.R., 2008. Mangrove production and carbon sinks: a revision of global budget estimates. Global Biogeochemical Cycling, in press.

Dahl et al., 2004 B. Dahl, J. Bojesen-Koefoed, A. Holm, H. Justwan, E. Rasmussen and E. Thomsen, A new approach to interpreting Rock-Eval S2 and TOC data for kerogen quality assessment, Organic Geochemistry 35 (2004), pp. 1461-1477.

Di-Giovanni et al., 1998 C. Di-Giovanni, J.-R. Disnar, M. Campy, V. Bichet and B. Guillet, Geochemical characterization of soil organic matter and variability of a post glacial detrital organic supply (Chaillexon lake, France), Earth Surface Processes and Landforms 23 (1998), pp. 1057-1069.

Disnar and Trichet, 1984 J.-R. Disnar and J. Trichet, The influence of various divalent cations $\left(\mathrm{Pb}^{2+}, \mathrm{Cu}^{2+}, \mathrm{Pb}^{2+}, \mathrm{Co}^{2+}, \mathrm{Ni}^{2+}, \mathrm{Zn}^{2+}, \mathrm{Mn}^{2+}\right)$ on thermally induced evolution of organic matter isolated from an algal mat, Organic Geochemistry 6 (1984), pp. 865-874.

Disnard et al., 2003 J.-R. Disnard, B. Guillet, D. Keravis, C. Di-Giovanni and D. Sebag, Soil organic matter (SOM) characterization by Rock-Eval pyrolysis: scope and limitations, Organic Geochemistry 34 (2003), pp. 327-343.

Espitalié et al., 1977 J. Espitalié, J.L. Laporte, M. Madec, F. Marquis, P. Leplat, J. Paulet and A. Boutefeu, Méthode rapide de caractérisation de roches mères, de leur potentiel pétrolier et de leur degré d'évolution, Revue de l'Institut Français du Pétrole 32 (1977), pp. 23-42.

Espitalié et al., 1985 J. Espitalié, G. Deroo and F. Marquis, La pyrolise Rock-Eval et ses applications, Revue de l'Institut Francais du Pétrole 40 (1985), pp. 563-579

Freudenthal et al., 2001 T. Freudenthal, T. Wagner, F. Wenzhöfer, M. Zabel and G. Wefer, Early diagenesis of organic matter from sediments of the eastern subtropical Atlantic: evidence from stable nitrogen and carbon isotopes, Geochimica et Cosmochimica Acta $\mathbf{6 5}$ (2001), pp. 1795-1808.

Fromard et al., 1998 F. Fromard, H. Puig, E. Mougin, G. Marty, J.L. Betoulle and L. Cadamuro, Structure, above ground biomass and dynamics of mangrove ecosystems: new data from French Guiana, Oecologia 115 (1998), pp. 39-53.

Hedges et al., 1986 J.I. Hedges, W.A. Clark, P.D. Quay, J.E. Richey, A.H. Devol and U.M. Santos, Composition and fluxes of particulate organic material in the Amazon River, Limnology and Oceanography 31 (1986), pp. 717-738. 
Hedges et al., 1994 J.I. Hedges, G.L. Cowie, J.E. Richey, P.D. Quay, R. Benner, M. Strom and B.R. Forsberg, Origins and processing of organic matter in the Amazon River as indicated by carbohydrates and amino acids, Limnology and Oceanography 39 (1994), pp. 743-761.

Hesse, 1961 P.R. Hesse, Some differences between the soils of Rhizophora and Avicennia mangrove swamp in Sierra Leone, Plant and Soil 14 (1961), pp. 335-346.

Hetényi et al., 2005 M. Hetényi, T. Nyilas and T.M. Toth, Stepwise Rock-Eval pyrolysis as a tool for typing heterogeneous organic matter in soils, Journal of Analytical and Applied Pyrolysis 74 (2005), pp. 45-54.

Jacob et al., 2004 J. Jacob, J.-R. Disnar, M. Boussafir, A. Sifeddine, B. Turcq and A.L. Spadano Albuquerque, Major environmental changes recorded by lacustrine sedimentary organic matter since the last glacial maximum near the equator (Lagoa do Caço, NE Brazil), Palaeogeography, Palaeoclimatology, Palaeoecology 205 (2004), pp. 183-197.

Kristensen et al., 2000 E. Kristensen, F.Ø. Andersen, N. Holmboe, M. Holmer and N. Thongtham, Carbon and nitrogen mineralization in sediments of the Bangrong mangrove area, Phuket, Thailand, Aquatic Microbial Ecology 22 (2000), pp. 199-213.

Kristensen et al., 2008 Kristensen, E., Bouillon, S., Dittmar, T., Marchand, C., 2008. Organic carbon dynamics in mangrove ecosystems. Aquatic Botany, in press.

Lafargue et al., 1998 E. Lafargue, F. Marquis and D. Pillot, Rock-Eval 6 applications in hydrocarbon exploration, production and soil contamination studies, Revue de l'Institut Français du Pétrole 53 (1998), pp. 421-437.

Lallier-Vergès et al., 1998 E. Lallier-Vergès, B.P. Perrussel, J.-R. Disnar and F. Baltzer, The relationship between environmental conditions and the diagenetic evolution of organic matter derived from higher plant in a present mangrove swamp system (Guadeloupe, French West Indies), Organic Geochemistry 29 (1998), pp. 1663-1686.

Lüniger and Schwark, 2002 G. Lüniger and L. Schwark, Characterisation of sedimentary organic matter by bulk and molecular geochemical proxies: an example from an Oligocene maar-type Lake Enspel, Germany, Sedimentary Geology 148 (2002), pp. 275-288.

Marchand et al., 2003 C. Marchand, E. Lallier-Vergès and F. Baltzer, The composition of sedimentary organic matter in relation to the dynamic features of a mangrove-fringed coast in French Guiana, Estuarine Coastal and Shelf Sciences 56 (2003), pp. 119-130.

Marchand et al., 2004 C. Marchand, F. Baltzer, E. Lallier-Vergès and P. Albéric, Pore water chemistry in mangrove sediments in relationship to species composition and developmental stage (French Guiana), Marine Geology 208 (2004), pp. 361-381.

Marchand et al., 2005 C. Marchand, J.-R. Disnar, E. Lallier-Vergès and N. Lottier, Early diagenesis of carbohydrates and lignin in mangrove sediments subject to variable redox conditions (French Guiana), Geochimica et Cosmochimica Acta 69 (2005), pp. 131-142. 
Marchand et al., 2006a C. Marchand, E. Lallier-Vergès, F. Baltzer, P. Albéric, D. Cossa and P. Baillif, Heavy metals distribution in mangrove sediments along the mobile coastline of French Guiana, Marine Chemistry 98 (2006), pp. 1-17.

Marchand et al., 2006b C. Marchand, P. Albéric, E. Lallier-Vergès and F. Baltzer, Distribution and characteristics of dissolved organic matter in mangrove sediments pore waters along the coastline of French Guiana, Biogeochemistry 81 (2006), pp. 59-75.

McKee, 1995 K.L. McKee, Seedlings recruitment patterns in a Belizean mangrove forest: effects of establishment ability and physico-chemical factors, Oecologia 101 (1995), pp. 448460 .

Meyers, 1997 P.A. Meyers, Organic and geochemical proxies of paleooceanographic, paleolimnologic and paleoclimatic processes, Organic Geochemistry 27 (1997), pp. 213-250.

Meyers and Lallier-Vergès, 1999 P.A. Meyers and E. Lallier-Vergès, Lacustrine records of changes in Late Quaternary continental environments and climates: an overview of sedimentary organic matter indicators, Journal of Paleolimnology 21 (1999), pp. 345-372.

Parra and Pujos, 1998 M. Parra and M. Pujos, Origin of late Holocene fine-grained sediments on the French Guiana shelf, Continental Shelf Research 18 (1998), pp. 1613-1629.

Patience et al., 1996 A.J. Patience, E. Lallier-Vergès, P. Albéric, N.P. Tribovillard and A. Desprairies, Impact of early diagenesis on the organo-mineral composition of recent lacustrine sediment. Le lac du Bouchet (France), Quaternary Science Reviews 15 (1996), pp. $213-222$.

Sachsenhofer et al., 2008 Sachsenhofer, R.F., Stummer, B., Georgiev, G., Dellmour, R., Bechtel, A., Gratzer R., Ćorić, S., 2008. Depositional environment and hydrocarbon source potential of the Oligocene Ruslar Formation (Kamchia Depression; Western Black Sea). Marine and Petroleum Geology, in press.

Sanei et al., 2005 H. Sanei, L.D. Stasiuk and F. Goodarzi, Petrological changes occurring in organic matter from Recent lacustrine sediments during thermal alteration by Rock-Eval pyrolysis, Organic Geochemistry 36 (2005), pp. 1190-1203.

Scholander et al., 1955 P.F. Scholander, L. Van dam and S.I. Scholander, Gas exchange in the roots of mangrove, American Journal of Botany 42 (1955), pp. 92-98.

Sebag et al., 2006 D. Sebag, J.-R. Disnar, B. Guillet, C. Di-Giovanni, E.P. Verrecchia and A. Durand, Monitoring organic matter dynamics in soil profiles by 'Rock-Eval pyrolysis': bulk characterization and quantification of degradation, European Journal of Soil Science 57 (2006), pp. 344-355.

Tamburini et al., 2002 F. Tamburini, S. Huon, P. Steinman, F.E. Grousset, T. Adatte and K.B. Föllmi, Dysaerobic conditions during Heinrich events 4 and 5: evidence from phosphorus distribution in a North Atlantic deep-sea core, Geochimica et Cosmochimica Acta 66 (2002), pp. 4069-4083. 
Versteegh et al., 2004 G.J.M. Versteegh, E. Schefuß, L. Dupont, F. Marret, J.S. SinningheDamsté and J.H.F. Jansen, Taraxerol and Rhizophora pollen as proxies for tracking past mangrove ecosystem, Geochimica et Cosmochimica Acta 68 (2004), pp. 411-422.

Zhu et al., 2002 Z. Zhu, R.C. Aller and J. Mack, Stable carbon isotope cycling in mobile coastal muds of Amapa, Brazil, Continental Shelf Research 22 (2002), pp. 2065-2079. 


\section{Figures}

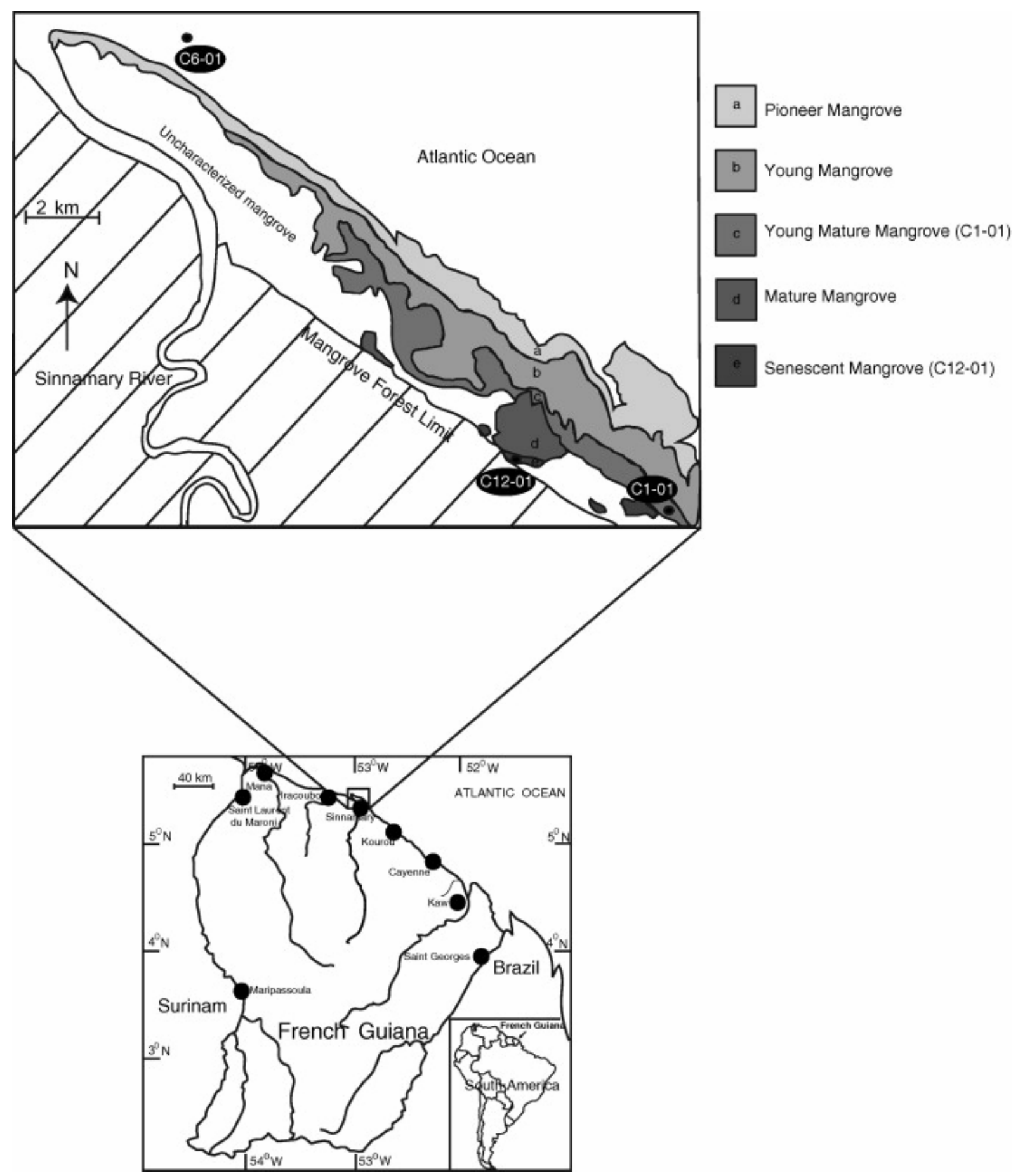

Fig. 1. Map of the study area (Sinnamary, French Guiana) showing location of cores. Mangrove zonation adapted from Fromard et al. (1998). 

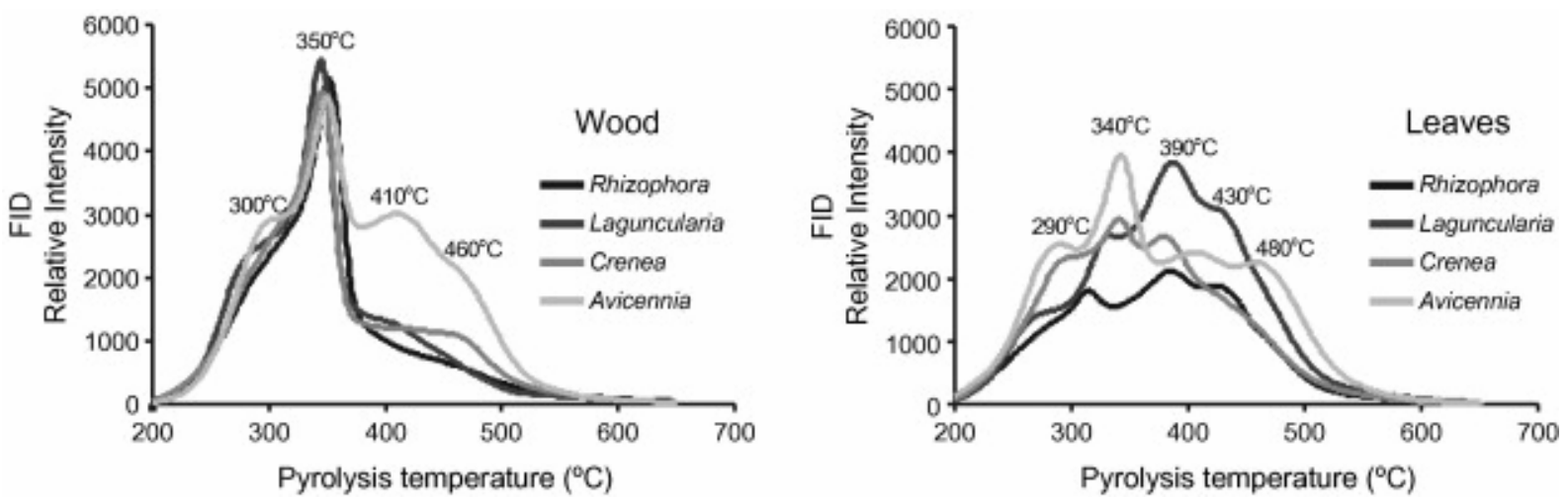

Fig. 2. FID pyrograms of leaf and woody tissue of plant developing in the mangrove swamps (Rhizophora mangle, Laguncularia racemosa, Crenea maritima, and Avicennia germinans). 

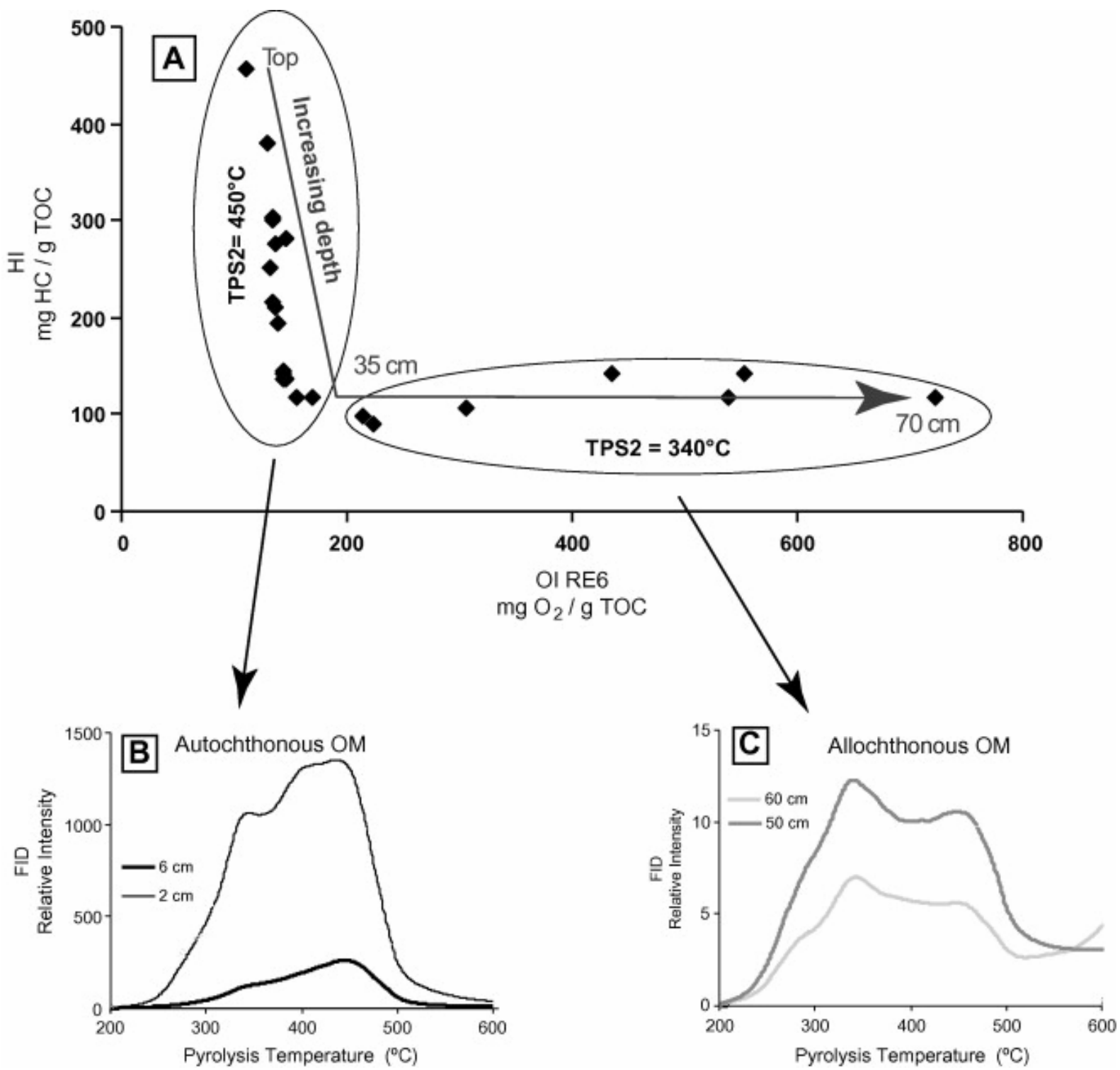

Fig. 3. Rock-Eval parameters as tools for identifying OM sources and following OM diagenesis (senescent forest). (A) OIRE6 vs. HI; samples circled on the left are from the upper $35 \mathrm{~cm}$ and were all characterized by TPS 2 values close to $450{ }^{\circ} \mathrm{C}$; samples circled on the right are from below $35 \mathrm{~cm}$ depth and were all characterized by TPS2 values close to $340{ }^{\circ} \mathrm{C}$. (B) FID pyrograms of samples from the upper core, with TPS2 at $450{ }^{\circ} \mathrm{C}$. (C) FID pyrograms of samples from the bottom core, with TPS 2 at $340{ }^{\circ} \mathrm{C}$. 
A $--\mathrm{OlCO}_{2}\left(\mathrm{mg} \mathrm{CO}_{2} / \mathrm{g} \mathrm{TOC}\right)$
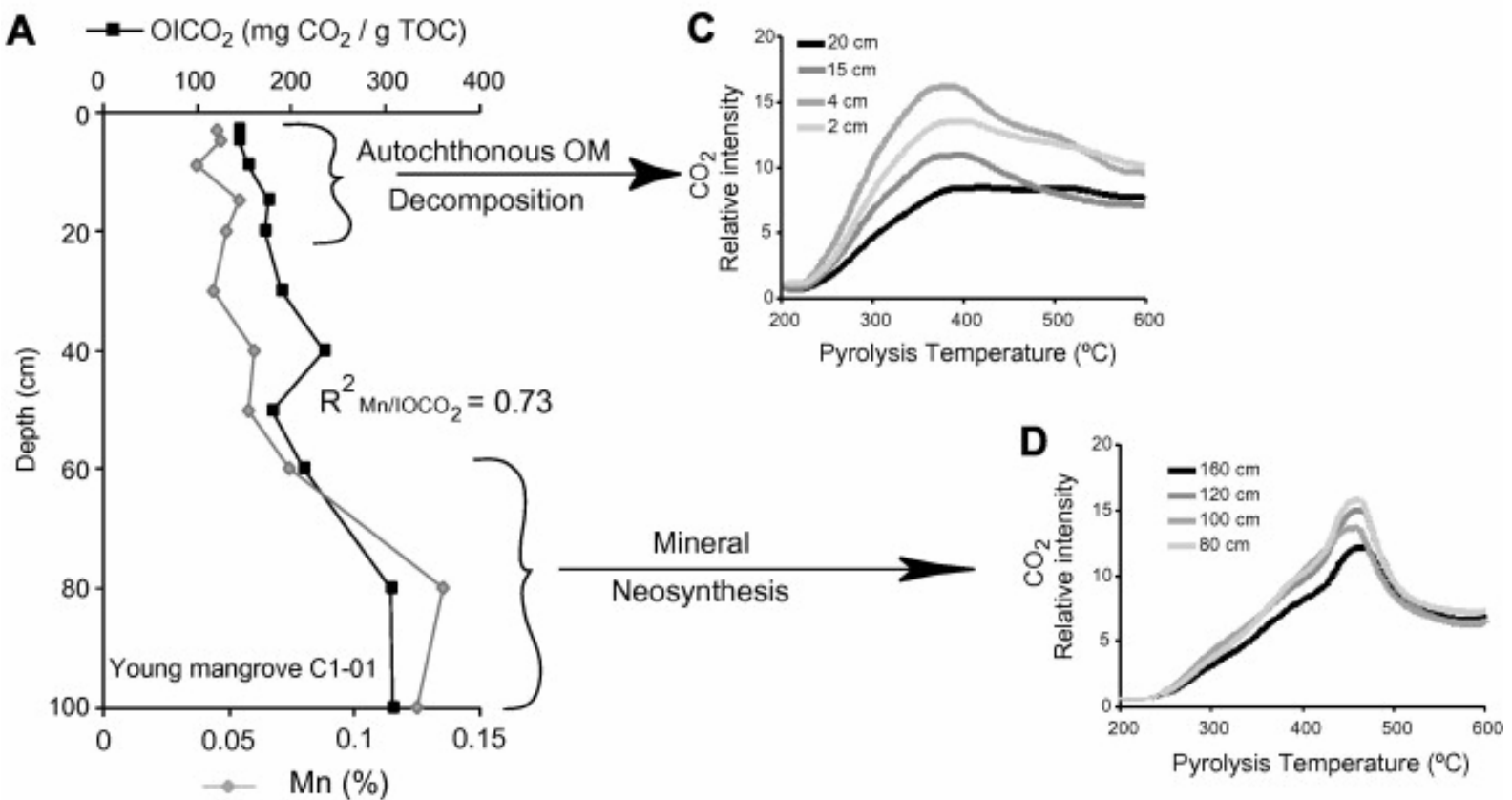

B

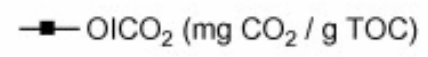

E
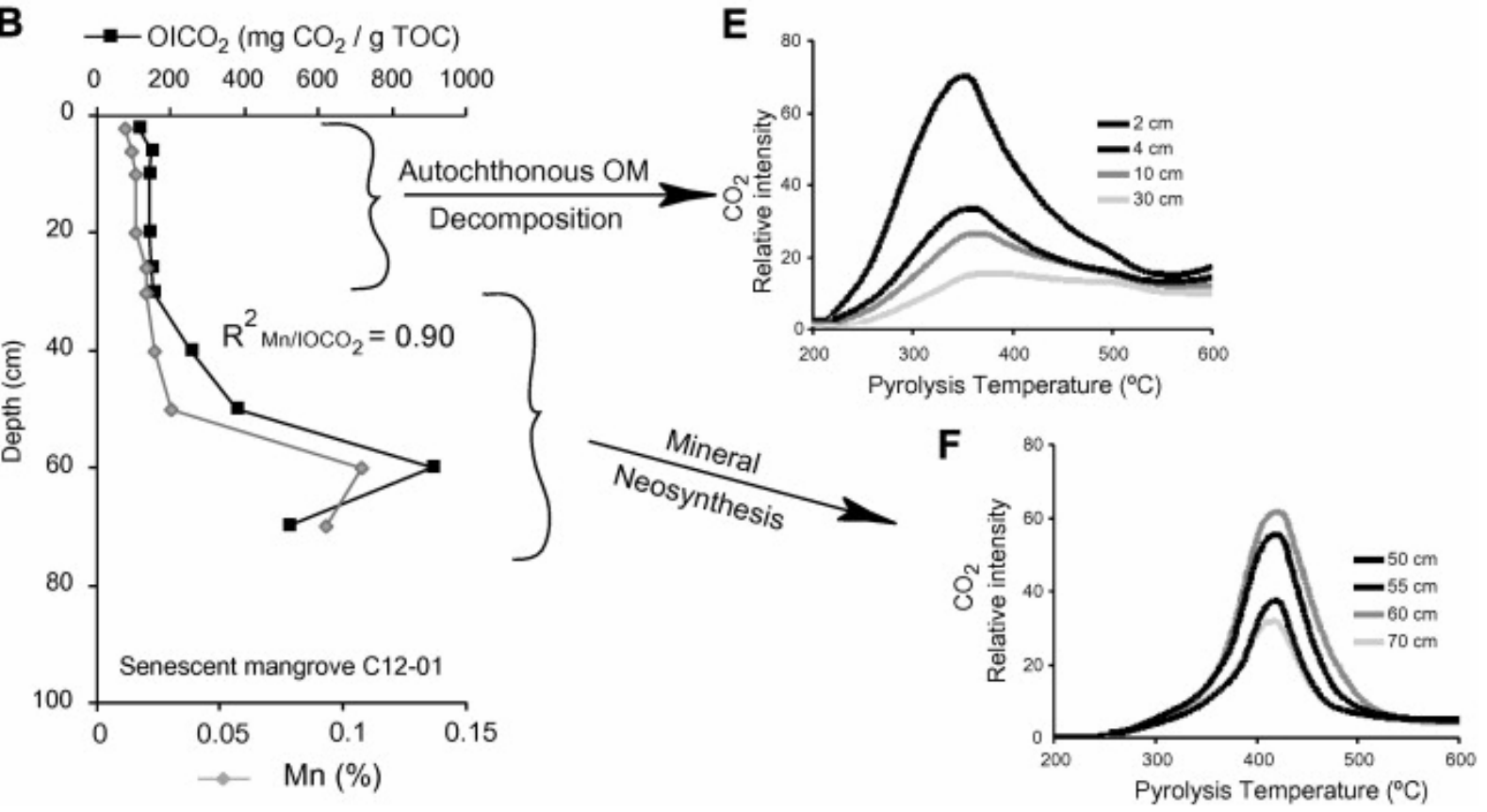

Fig. 4. Depth profiles of $\mathrm{OICO}_{2}$ values and $\mathrm{Mn}$ concentration beneath the young mature (A) and the senescent (B) mangrove swamps, and $\mathrm{CO}_{2}$ pyrograms of the corresponding samples $(\mathrm{C}-\mathrm{F})$. 


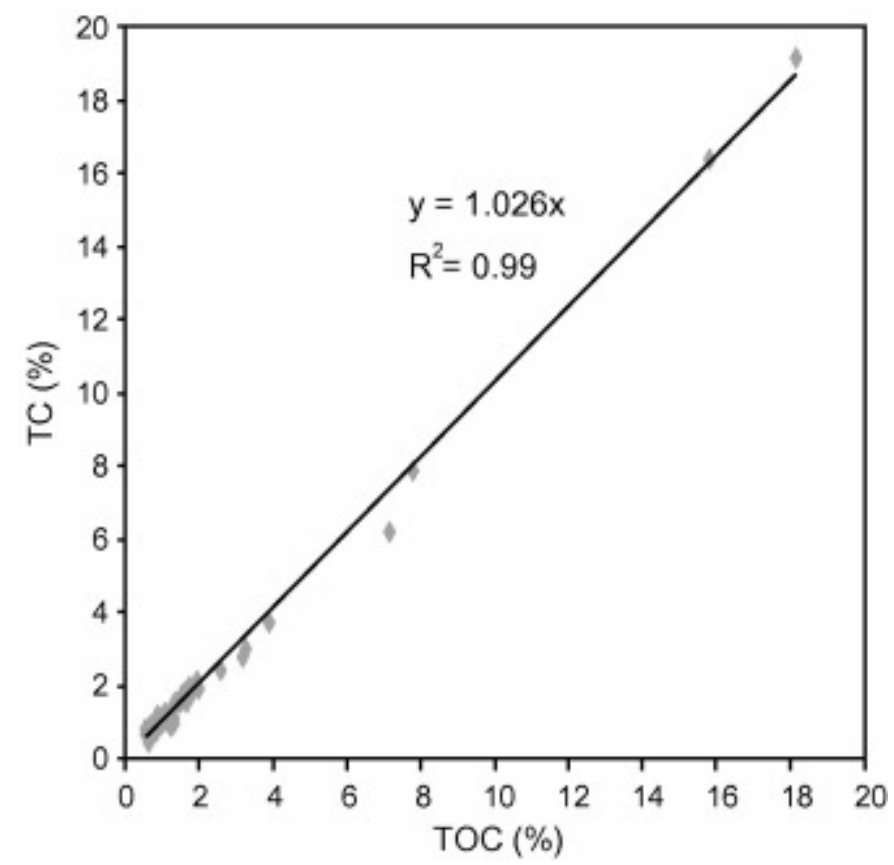

Fig. 5. Correlation between TOC content (\%) determined from Rock-Eval pyrolysis and total carbon content (\%) determined from classical combustion with a LECO CNS-2000 analyser.

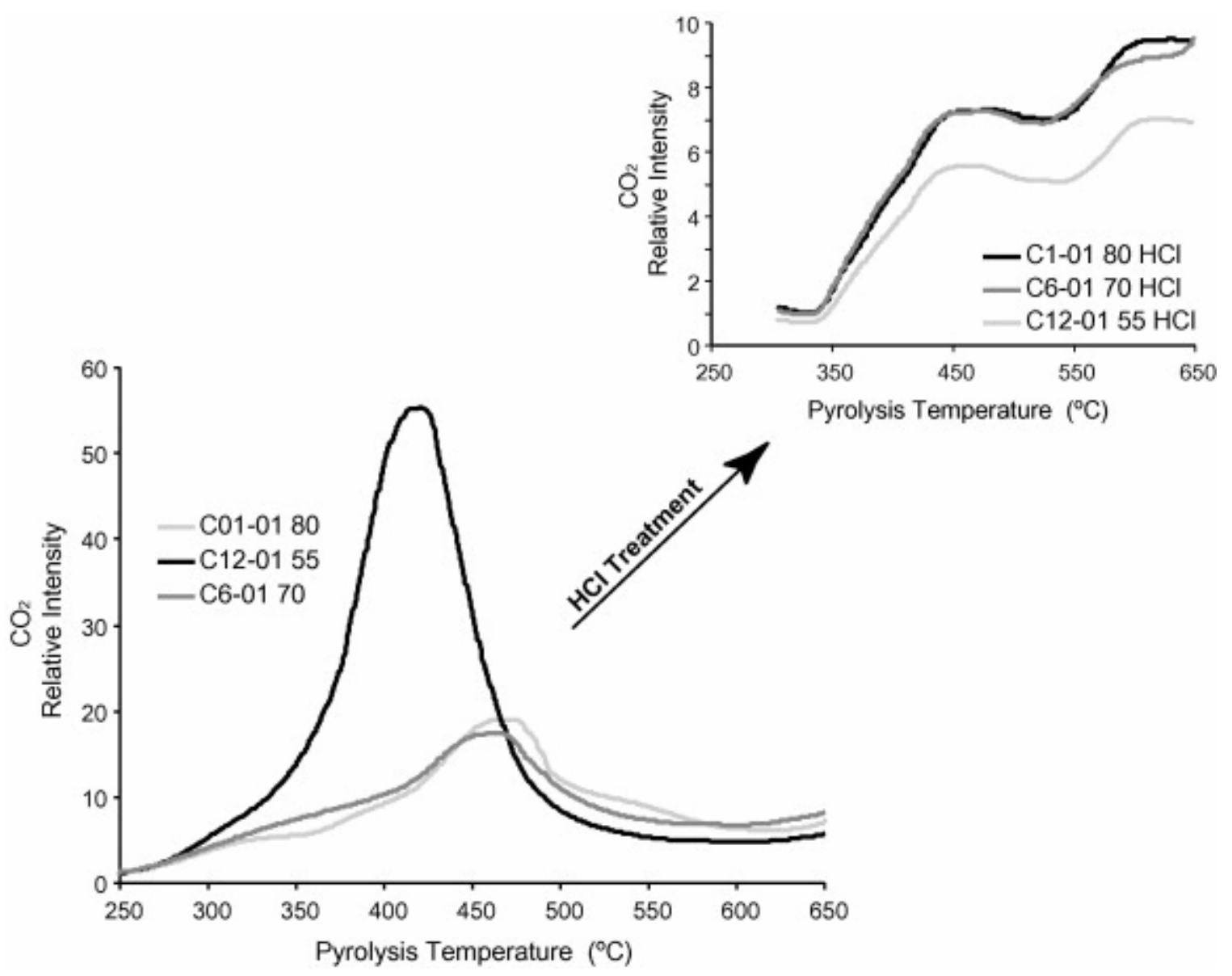

Fig. 6. $\mathrm{CO}_{2}$ pyrograms of samples characterized by high $\mathrm{OICO}_{2}$ values before and after $\mathrm{HCl}$ treatment. 

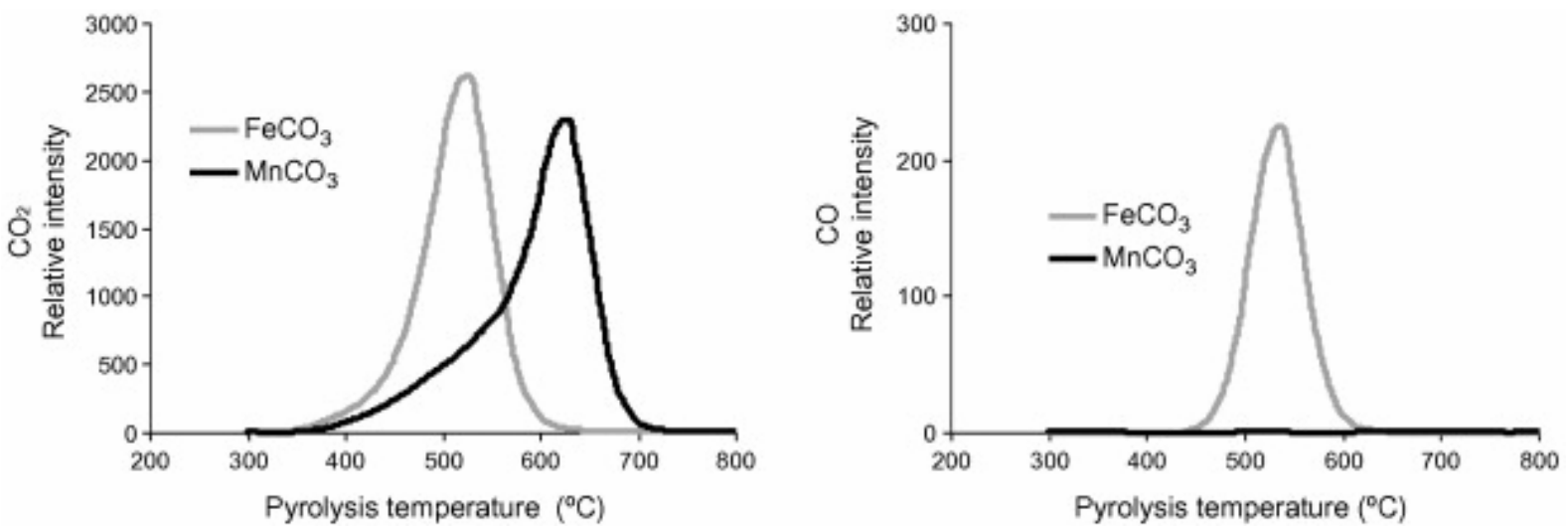

Fig. 7. $\mathrm{CO}_{2}$ and $\mathrm{CO}$ pyrograms of $\mathrm{FeCO}_{3}$ and $\mathrm{MnCO}_{3}$. 


\section{Tables}

Table 1. : Main Rock-Eval parameters for mangrove plant species in Sinnamary's mangrove (Rhizophora mangle, Laguncularia racemosa, Crenea maritima, and Avicennia germinans)

\begin{tabular}{|c|c|c|c|c|c|c|c|}
\hline Samples & $\begin{array}{l}\text { TOC } \\
(\%)\end{array}$ & $\begin{array}{l}\mathrm{HI} \quad(\mathrm{mg} \\
\mathrm{HC} \mathrm{g}^{-1} \\
\text { TOC) }\end{array}$ & $\begin{array}{l}\text { OIRE6 (mg } \\
\mathrm{O}_{2} \mathrm{~g}^{-1} \text { TOC) }\end{array}$ & $\begin{array}{l}\mathrm{OICO}_{\mathrm{CO} \mathrm{g}^{-1}} \quad(\mathrm{mg} \\
\text { TOC) }\end{array}$ & $\begin{array}{l}\mathrm{OICO}_{2} \quad(\mathrm{mg} \\
\mathrm{CO}_{2} \mathrm{~g}^{-1} \\
\text { TOC) }\end{array}$ & $\begin{array}{l}\text { TPS2 } \\
\left({ }^{\circ} \mathrm{C}\right)\end{array}$ & $\begin{array}{l}\mathrm{TPS3CO}_{2} \\
\left({ }^{\circ} \mathrm{C}\right)\end{array}$ \\
\hline $\begin{array}{l}\text { A. germinans } \\
\text { leaf }\end{array}$ & 34 & 556 & 166 & 50 & 189 & 342 & 294 \\
\hline $\begin{array}{l}\text { A. germinans } \\
\text { wood }\end{array}$ & 42 & 480 & 134 & 58 & 138 & 350 & 363 \\
\hline $\begin{array}{l}R . \quad \text { mangle } \\
\text { leaf }\end{array}$ & 40 & 287 & 118 & 47 & 126 & 385 & 300 \\
\hline $\begin{array}{l}R . \quad \text { mangle } \\
\text { wood }\end{array}$ & 40 & 323 & 151 & 83 & 142 & 351 & 364 \\
\hline $\begin{array}{l}\text { L. racemosa } \\
\text { leaf }\end{array}$ & 42 & 424 & 143 & 44 & 162 & 387 & 293 \\
\hline $\begin{array}{l}\text { L. racemosa } \\
\text { wood }\end{array}$ & 39 & 360 & 160 & 82 & 156 & 345 & 359 \\
\hline $\begin{array}{l}\text { C. maritima } \\
\text { leaf }\end{array}$ & 35 & 420 & 154 & 49 & 173 & 341 & 298 \\
\hline $\begin{array}{l}\text { C. maritima } \\
\text { wood }\end{array}$ & 37 & 389 & 163 & 78 & 163 & 346 & 356 \\
\hline
\end{tabular}


Table 2. : Main Rock-Eval parameters for core collected in the unvegetated sediment (C6-01)

\begin{tabular}{|c|c|c|c|c|c|c|c|}
\hline $\begin{array}{l}\text { Depth } \\
\text { (cm) }\end{array}$ & $\begin{array}{l}\text { TOC } \\
(\%)\end{array}$ & $\begin{array}{l}\mathrm{HI} \quad(\mathrm{mg} \\
\mathrm{HC} \mathrm{g}^{-1} \\
\text { TOC) }\end{array}$ & $\begin{array}{l}\text { OIRE6 (mg } \\
\mathrm{O}_{2} \mathrm{~g}^{-1} \text { TOC) }\end{array}$ & $\begin{array}{l}\mathrm{OICO}_{\mathrm{ICg}}(\mathrm{mg} \\
\left.\mathrm{COg}^{-1} \mathrm{TOC}\right)\end{array}$ & $\begin{array}{l}\mathrm{OICO}_{2} \quad(\mathrm{mg} \\
\mathrm{CO}_{2} \mathrm{~g}^{-1} \text { TOC) }\end{array}$ & $\begin{array}{l}\text { TPS2 } \\
\left({ }^{\circ} \mathrm{C}\right)\end{array}$ & $\begin{array}{l}\mathrm{TPS3CO}_{2} \\
\left({ }^{\circ} \mathrm{C}\right)\end{array}$ \\
\hline 5 & 0.92 & 109 & 237 & 54 & 283 & 378 & 400 \\
\hline 10 & 0.61 & 158 & 281 & 52 & 346 & 634 & 400 \\
\hline 15 & 0.62 & 134 & 265 & 55 & 320 & 367 & 400 \\
\hline 20 & 1.26 & 130 & 194 & 54 & 224 & 363 & 400 \\
\hline 30 & 0.54 & 143 & 342 & 73 & 413 & 376 & 400 \\
\hline 40 & 0.67 & 134 & 266 & 53 & 325 & 648 & 400 \\
\hline 50 & 0.62 & 157 & 312 & 65 & 378 & 372 & 400 \\
\hline 60 & 0.61 & 127 & 279 & 65 & 332 & 376 & 400 \\
\hline 70 & 0.58 & 159 & 291 & 55 & 356 & 382 & 400 \\
\hline 80 & 0.52 & 159 & 346 & 65 & 424 & 376 & 400 \\
\hline
\end{tabular}


Table 3.: Main Rock-Eval parameters for core collected beneath young mature Avicennia mangrove forest (C1-01)

\begin{tabular}{|c|c|c|c|c|c|c|c|}
\hline $\begin{array}{l}\text { Depth } \\
\text { (cm) }\end{array}$ & $\begin{array}{l}\text { TOC } \\
(\%)\end{array}$ & $\begin{array}{l}\mathrm{HI} \quad(\mathrm{mg} \\
\mathrm{HC} \mathrm{g}^{-1} \\
\text { TOC) }\end{array}$ & $\begin{array}{l}\text { OIRE6 (mg } \\
\mathrm{O}_{2} \mathrm{~g}^{-1} \text { TOC) }\end{array}$ & $\begin{array}{l}\mathrm{OICO}_{\mathrm{CO} \mathrm{g}^{-1}} \quad(\mathrm{mg} \\
\mathrm{TOC})\end{array}$ & $\begin{array}{l}\mathrm{OICO}_{2} \quad(\mathrm{mg} \\
\mathrm{CO}_{2} \mathrm{~g}^{-1} \text { TOC) }\end{array}$ & $\begin{array}{l}\text { TPS2 } \\
\left({ }^{\circ} \mathrm{C}\right)\end{array}$ & $\begin{array}{l}\mathrm{TPS3CO}_{2} \\
\left({ }^{\circ} \mathrm{C}\right)\end{array}$ \\
\hline 2 & 2.06 & 174 & 156 & 64 & 164 & 447 & 399 \\
\hline 4 & 2.73 & 224 & 143 & 68 & 144 & 448 & 374 \\
\hline 6 & 2.77 & 203 & 139 & 60 & 144 & 448 & 384 \\
\hline 8 & 1.24 & 157 & 163 & 67 & 171 & 450 & 383 \\
\hline 10 & 2.34 & 172 & 146 & 59 & 153 & 448 & 378 \\
\hline 15 & 1.48 & 150 & 159 & 55 & 175 & 444 & 388 \\
\hline 20 & 1.27 & 143 & 165 & 71 & 171 & 349 & 381 \\
\hline 25 & 0.82 & 137 & 229 & 99 & 236 & 355 & 394 \\
\hline 30 & 1.05 & 127 & 170 & 58 & 188 & 342 & 394 \\
\hline 40 & 0.70 & 166 & 201 & 52 & 235 & 366 & 399 \\
\hline 50 & 0.86 & 160 & 170 & 69 & 179 & 353 & 399 \\
\hline 60 & 0.67 & 170 & 190 & 60 & 213 & 354 & 400 \\
\hline 80 & 0.59 & 140 & 260 & 66 & 305 & 350 & 400 \\
\hline 100 & 0.60 & 146 & 258 & 59 & 308 & 350 & 400 \\
\hline 120 & 0.56 & 158 & 267 & 54 & 324 & 358 & 400 \\
\hline 160 & 0.57 & 167 & 233 & 67 & 268 & 350 & 400 \\
\hline
\end{tabular}


Table 4.: Main Rock-Eval parameters for core collected beneath senescent Avicennia mangrove forest (C12-01)

\begin{tabular}{|c|c|c|c|c|c|c|c|}
\hline $\begin{array}{l}\text { Depth } \\
\text { (cm) }\end{array}$ & $\begin{array}{l}\text { TOC } \\
(\%)\end{array}$ & $\begin{array}{l}\mathrm{HI} \quad(\mathrm{mg} \\
\mathrm{HC} \mathrm{g}^{-1} \\
\text { TOC) }\end{array}$ & $\begin{array}{l}\text { OIRE6 (mg } \\
\mathrm{O}_{2} \mathrm{~g}^{-1} \text { TOC) }\end{array}$ & $\begin{array}{l}\mathrm{OICO}_{\mathrm{CO} \mathrm{g}^{-1}} \text { TOC) }\end{array}$ & $\begin{array}{l}\mathrm{OICO}_{2} \quad(\mathrm{mg} \\
\left.\mathrm{CO}_{2} \mathrm{~g}^{-1} \mathrm{TOC}\right)\end{array}$ & $\begin{array}{l}\text { TPS2 } \\
\left({ }^{\circ} \mathrm{C}\right)\end{array}$ & $\begin{array}{l}\mathrm{TPS3CO}_{2} \\
\left({ }^{\circ} \mathrm{C}\right)\end{array}$ \\
\hline 2 & 14.09 & 456 & 111 & 48 & 115 & 434 & 350 \\
\hline 4 & 6.23 & 380 & 130 & 62 & 130 & 443 & 355 \\
\hline 6 & 3.60 & 282 & 145 & 71 & 145 & 445 & 371 \\
\hline 8 & 4.61 & 300 & 134 & 64 & 134 & 446 & 366 \\
\hline 10 & 4.43 & 276 & 137 & 62 & 139 & 450 & 361 \\
\hline 12 & 4.33 & 303 & 135 & 64 & 135 & 448 & 364 \\
\hline 14 & 3.71 & 251 & 131 & 64 & 130 & 450 & 367 \\
\hline 16 & 3.31 & 217 & 135 & 67 & 132 & 451 & 366 \\
\hline 18 & 4.02 & 210 & 136 & 65 & 136 & 451 & 366 \\
\hline 20 & 2.58 & 193 & 140 & 65 & 141 & 455 & 376 \\
\hline 24 & 2.33 & 146 & 143 & 70 & 142 & 455 & 384 \\
\hline 26 & 1.99 & 142 & 144 & 65 & 146 & 456 & 369 \\
\hline 28 & 1.72 & 117 & 156 & 61 & 166 & 453 & 384 \\
\hline 30 & 2.25 & 138 & 146 & 64 & 150 & 456 & 384 \\
\hline 35 & 2.85 & 116 & 170 & 72 & 177 & 456 & 369 \\
\hline 40 & 1.01 & 89 & 222 & 63 & 256 & 340 & 371 \\
\hline 45 & 0.86 & 98 & 214 & 62 & 245 & 339 & 391 \\
\hline 50 & 0.72 & 106 & 307 & 58 & 377 & 339 & 400 \\
\hline 55 & 0.62 & 118 & 539 & 102 & 661 & 342 & 400 \\
\hline 60 & 0.47 & 118 & 722 & 108 & 908 & 350 & 400 \\
\hline 65 & 0.48 & 142 & 552 & 89 & 690 & 336 & 400 \\
\hline 70 & 0.56 & 142 & 436 & 99 & 522 & 338 & 400 \\
\hline
\end{tabular}


Table 5. : Main Rock-Eval parameters for some samples before and after $\mathrm{HCl}$ treatment

\begin{tabular}{|c|c|c|c|c|c|c|c|}
\hline $\begin{array}{l}\text { Sample (core } \\
\text { number, } \\
\text { depth) }\end{array}$ & $\begin{array}{l}\text { TOC } \\
(\%)\end{array}$ & $\begin{array}{l}\mathrm{HI} \\
\mathrm{HC} \mathrm{g}{ }^{-1}(\mathrm{mg} \\
\text { TOC) }\end{array}$ & $\begin{array}{l}\text { OIRE6 (mg } \\
\mathrm{O}_{2} \mathrm{~g}^{-1} \text { TOC) }\end{array}$ & $\begin{array}{l}\mathrm{OICO}^{-1}(\mathrm{mg} \\
\mathrm{CO} \mathrm{g}^{-1} \\
\text { TOC) }\end{array}$ & $\begin{array}{l}\mathrm{OICO}_{2} \quad(\mathrm{mg} \\
\mathrm{CO}_{2} \mathrm{~g}^{-1} \\
\mathrm{TOC})\end{array}$ & $\begin{array}{l}\text { TPS2 } \\
\left({ }^{\circ} \mathrm{C}\right)\end{array}$ & $\begin{array}{l}\mathrm{TPS3CO}_{2} \\
\left({ }^{\circ} \mathrm{C}\right)\end{array}$ \\
\hline C12-01 2 & 14.09 & 456 & 111 & 48 & 115 & 434 & 350 \\
\hline $\begin{array}{l}\mathrm{C} 12-01 \\
2+\mathrm{HCl}\end{array}$ & 13.62 & 438 & 171 & 49 & 197 & 429 & 346 \\
\hline C12-01 20 & 4.02 & 210 & 136 & 65 & 136 & 451 & 366 \\
\hline $\begin{array}{l}\mathrm{C} 12-01 \\
20+\mathrm{HCl}\end{array}$ & 2.59 & 158 & 201 & 68 & 223 & 452 & 361 \\
\hline $\mathrm{C} 12-0155$ & 0.62 & 118 & 539 & 102 & 661 & 342 & 400 \\
\hline $\begin{array}{l}\mathrm{C} 12-01 \\
55+\mathrm{HCl}\end{array}$ & 0.56 & 147 & 278 & 133 & 277 & 464 & 363 \\
\hline C12-01 60 & 0.47 & 118 & 722 & 108 & 908 & 350 & 400 \\
\hline $\begin{array}{l}\mathrm{C} 12-01 \\
60+\mathrm{HCl}\end{array}$ & 0.45 & 116 & 109 & 112 & 62 & 446 & 364 \\
\hline C6-01 70 & 0.58 & 159 & 291 & 55 & 356 & 382 & 400 \\
\hline $\begin{array}{l}\mathrm{C} 6-01 \\
70+\mathrm{HCl}\end{array}$ & 0.57 & 91 & 351 & 157 & 360 & 650 & 380 \\
\hline C1-01 80 & 0.59 & 140 & 260 & 66 & 305 & 350 & 400 \\
\hline $\begin{array}{l}\mathrm{C} 1-01 \\
80+\mathrm{HCl}\end{array}$ & 0.57 & 103 & 362 & 172 & 363 & 650 & 389 \\
\hline
\end{tabular}

